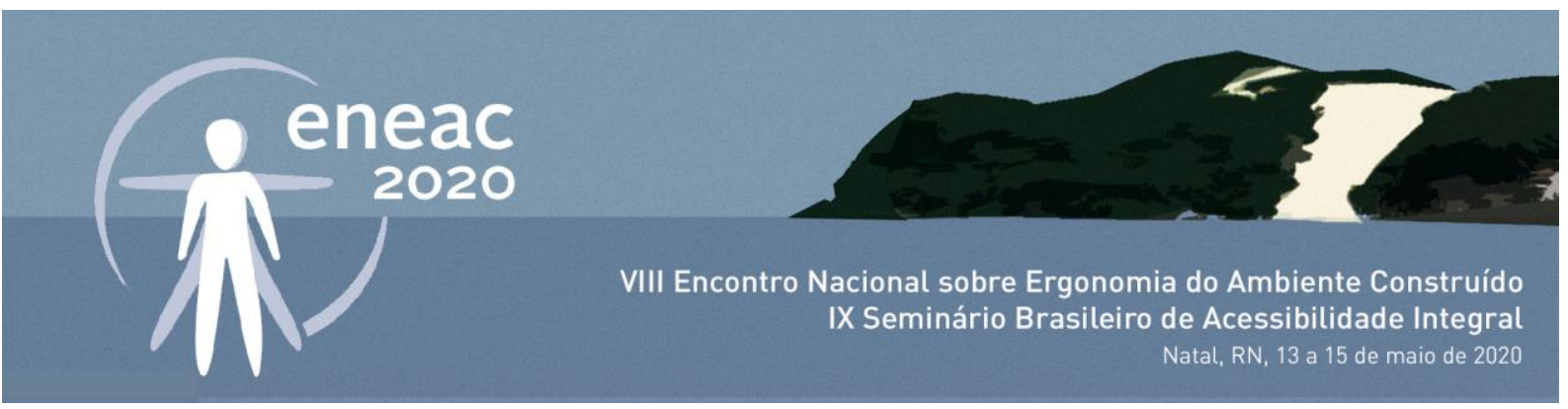

\title{
Acessibilidade no Centro de Fortaleza: os obstáculos para idosos e pessoas com mobilidade reduzida
}

\author{
Accessibility in the Fortaleza City Center: the obstacles for seniors \\ and people with reduced mobility
}

SUZY MARINHO DE ALMEIDA

Graduanda em Arquitetura e Urbanismo, Universidade Federal do Ceará, suzymarinho_@hotmail.com

LORENA MOREIRA CRUZ

Graduanda em Arquitetura e Urbanismo, Universidade Federal do Ceará, lorenamoreiira@gmail.com

SOFIA MARTINS DE SOUSA DIAS

Graduanda em Arquitetura e Urbanismo, Universidade Federal do Ceará, sofisdias@hotmail.com

RÍVIA NOBRE FEITOZA

Graduanda em Arquitetura e Urbanismo, Universidade Federal do Ceará, rivia.nobre@hotmail.com

\section{RESUMO}

O presente trabalho apresenta um diagnóstico das condições de acessibilidade em um recorte espacial do Centro da cidade de Fortaleza CE, com enfoque em apresentar os problemas de acessibilidade enfrentados por idosos ou pessoas com mobilidade reduzida. Faz parte de uma pesquisa de mestrado em andamento em que os alunos da Disciplina de Desenho Universal tiveram a oportunidade de participar, colaborando na pesquisa de campo com trechos determinados pela pesquisadora. Tendo em vista ser uma área com grande fluxo de transeuntes predominantes em transportes públicos ou alternativos ou a pé e ofertar uma variedade de serviços, o Centro da cidade deveria ser uma área com características adequadas e propícias para caminhabilidade, visando facilitar a circulação de todas as pessoas. Porém, é sabido que grande parte da cidade de Fortaleza não oferece tais condições a toda a população, sendo necessário, cada vez mais, o reconhecimento de tais problemas e a busca de intervenções urbanas que possibilitem melhorias.

Palavras chave: acessibilidade; Centro; idosos e autonomia. 


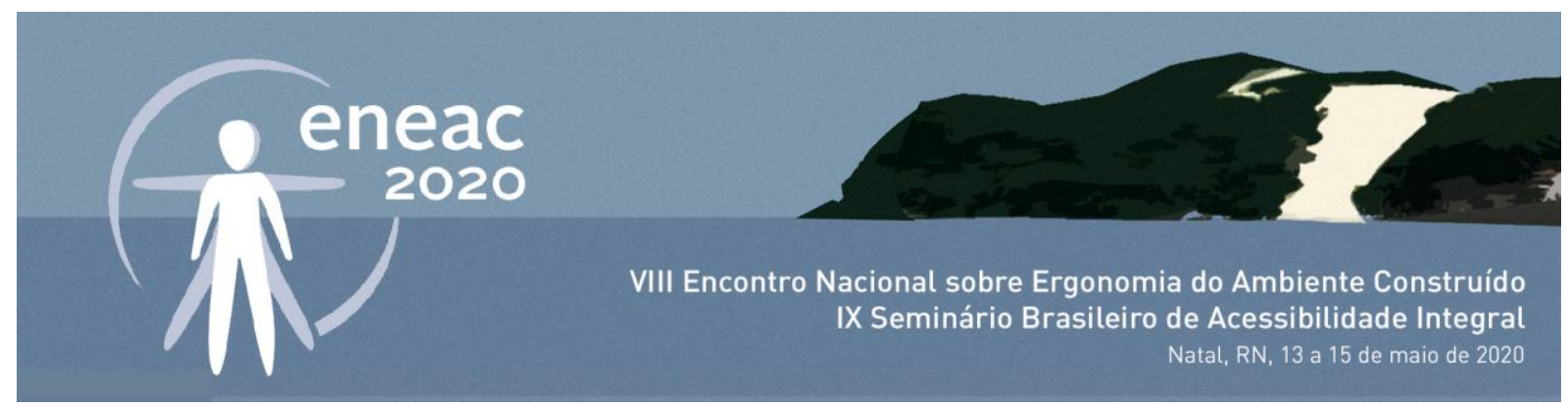

\section{ABSTRACT}

This paper presents a diagnosis of the accessibility conditions in a special cut of the Fortaleza CE City Center, focusing on presenting the accessibility problems faced by seniors or people with reduced mobility. It is part of an master's research in progress, where students from the Universal Drawing Discipline had the opportunity to participate, collaborating in the field research with areas selected by the researcher. This is an area with a large flow of pedestrians, coming predominant in public or alternative transport and by walk, and offer a variety of services, so this should be a neighborhood with adequate and conducive walking characteristics, aiming to facilitate the movement of all people. However, it is known that a large part of the city of Fortaleza does not offer such conditions to the entire population, and it is increasingly necessary to recognize such problems and look for urban interventions to ensure more improvements.

Keywords: accessibility; downtown; seniors and autonomy.

\section{INTRODUÇÃO}

O Centro da cidade de Fortaleza caracteriza-se, principalmente, por ser uma grande zona comercial, onde também se localizam diversos equipamentos e serviços. Entretanto, em seu uso e ocupação ainda é percebida uma parcela residencial significante. Essa configuração se dá devido ao seu histórico.

Fortaleza foi marcada por grandes mudanças urbanas ao longos do séculos XIX e XX, entre elas processos de melhorias e de êxodo rural, ampliando consideravelmente seu contingente populacional. A cidade passou por um desenvolvimento econômico, causando algumas alterações na configuração de certas áreas, ocorrendo de casas tradicionais passarem a servir para alguma atividade comercial. Botelho (2005) afirma que, no caso do Centro, como Fortaleza ainda não apresentava condições naturais para construção de um porto que pudesse suprir a maioria das atividades comerciais, houve um investimento em construções de atracadouros artificiais. Dessa forma, muitas residências do bairro passaram a servir de depósitos para suprir a demanda das atividades comerciais crescente, deslocando-se os proprietários para outras áreas da cidade.

Segundo o autor, nas décadas de 1940 e 1950, com a construção do Porto do Mucuripe, o bairro passou novamente por transformações, sofrendo progressivo esvaziamento e com os imóveis voltando a serem ocupados como moradias, depósitos e pequenos negócios, sendo instalada uma urbanização desorganizada.

A partir de tal trajetória, entende-se que grande parte de população que ainda habita no Centro de Fortaleza são moradores mais antigos, devido às novas ocupações seguirem a conformação comercial resultante dos processos descritos. Ademais, o bairro também é muito frequentado por idosos em busca de lazer e de serviços, como clínicas, além da considerável parcela ainda inserida no mercado de trabalho e que trabalham na região.

De antemão, afirma-se que no diagnóstico foi constatado sim o uso dos espaços do Centro de Fortaleza pelos idosos, sendo, em sua maioria, mulheres. Nesse sentido, a pesquisa busca analisar as possíveis dificuldades nos acessos e passeios, com enfoque para a questão do idoso, em área de estudo pré-estabelecida. 


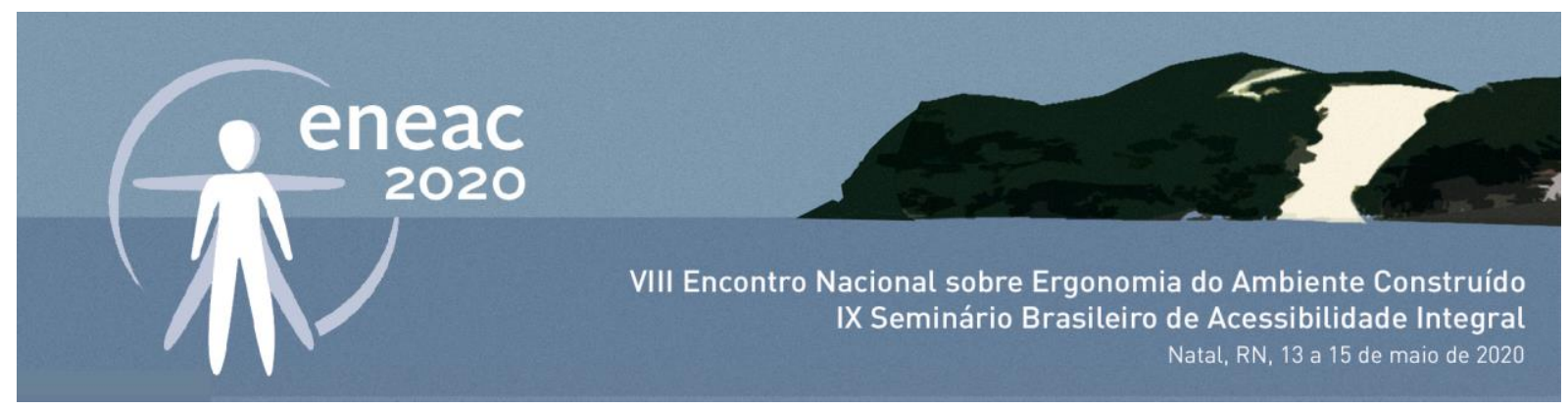

\section{METODOLOGIA}

A metodologia utilizada para realizar a pesquisa iniciou-se com um estudo bibliográfico, para a fundamentação teórica com base em conceitos e critérios de acessibilidade e aspectos referentes a vida e necessidades dos idosos, seguindo os parâmetros de acessibilidade encontrados na NBR 9050/2015. Deu-se continuidade com a pesquisa de campo do ambiente de estudo, o trecho que compreende os arredores da Praça Coração de Jesus no Centro de Fortaleza. A metodologia de campo se baseia Ornstein et al (1992) que trata da Avaliação Pós-Ocupação - APO, utilizando-se de levantamento métrico, registro fotográfico, entrevistas pontuais e preenchimento de um roteiro estabelecido - checklist.

As entrevistas foram realizadas com idosos encontrados durante a visita técnica, para isso adotamos a idade de 60 anos estabelecida pela Organização das Nações Unidas (ONU, 2005) idade também adotada pelo Estatuto do Idoso, que entrou em vigor a partir de 31 de dezembro de 2003. Coletamos informações como, qual atividade o idoso realizava no Centro, seu nome, idade e meio de transporte utilizado. Além do marco de 60 anos, observamos transeuntes que apresentavam alguma mobilidade reduzida.

Durante a pesquisa os aspectos avaliados foram os seguintes:

1. Quanto aos aspectos gerais do local:

Presença de idosos (quantidade e gênero);

Presença de lixo no chão, presença de lixeiras;

Presença de bocas de lobo e grelhas que possam provocar acidentes ou estejam mal localizadas;

2. Quanto à acessibilidade:

Presença de pavimentação regular, firme e contínua;

Presença de faixa contínua para circulação de pedestres de, no mínimo, $1.20 \mathrm{~m}$;

Presença de obstáculos aéreos (altura menor que 2.10m);

A faixa livre apresenta inclinação transversal maior que 3\%;

Presença de algum obstáculo na faixa livre (ex: bancos, postes, telefones públicos, bancas);

Presença de rebaixamento de guia da calçada em travessia de esquina e/ou em meio de quadra;

3. Quanto às travessias:

As travessias semaforizadas possuem faixa de pedestres;

Presença de faixa de pedestres sinalizando travessias não semaforizadas;

Presença de semáforo para pedestres;

Presença de faixa elevada conectando calçadas;

4. Quanto ao estacionamento:

Presença do sistema de Zona Azul;

Presença de vagas destinadas a idosos;

Presença de sinalização vertical e horizontal da(s) vaga(s) para idosos; 


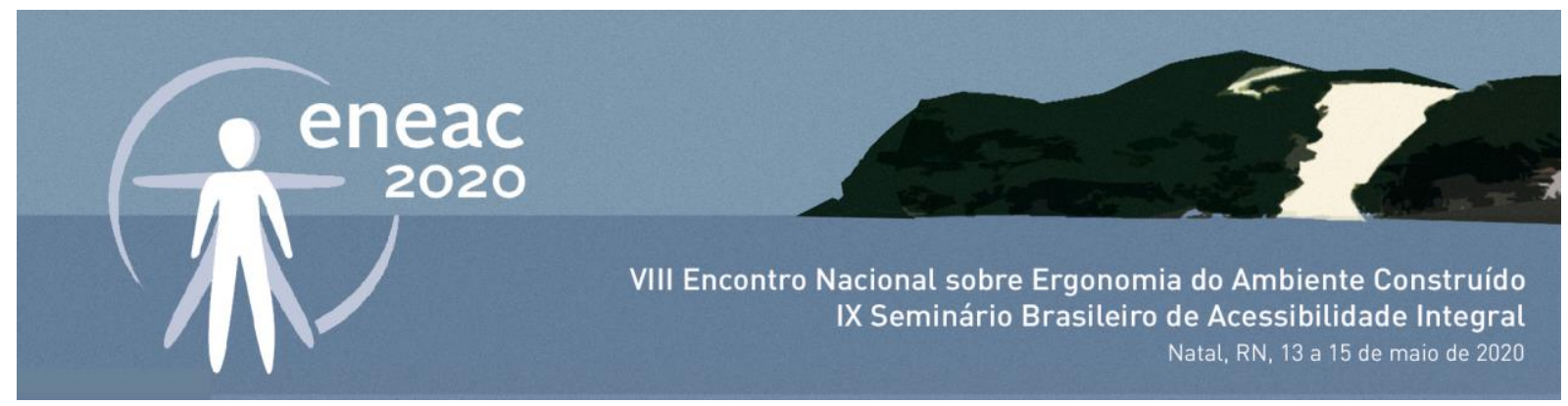

5. Quanto ao mobiliário:

Presença de bancos;

Presença de telefone público;

Presença de poste de iluminação pública;

Presença de jardineiras;

6. Quanto ao transporte público:

Presença de pontos de ônibus;

Presença de sinalização vertical nos pontos de ônibus;

Presença de abrigo na parada de ônibus;

Presença de abrigo na plataforma;

Presença de proteção física nas plataformas (guarda-corpo);

Os ônibus ficam com as suas portas niveladas com as plataformas;

As plataformas têm dimensões adequadas de maneira que não provoque acidentes.

Foram realizadas duas visitas ao local para levantamento espacial, anotações e documentação via fotografia, posteriormente mais uma visita para levantamento de dados sobre o uso dos transportes públicos por idosos, adotamos um intervalo de duas horas no qual quantificamos quantas pessoas embarcavam e desembarcavam no terminal e quantas dessas eram idosas. Observamos um fluxo constante de idosos utilizando o transporte público.

Ao final da pesquisa, para facilitar a análise da nossa área de estudo, dividimos o recorte espacial adotando uma nomenclatura para cada trecho avaliado, sequencialmente facilitando a fase de diagnósticos e conclusões.

\section{3 ÁREA DE ESTUDO}

A área definida para estudo (mapa 1) concentra-se nos arredores do Parque da Liberdade, mais conhecido como Parque das Crianças, e da Praça Coração de Jesus. Essa região, além de muito movimentada pelo comércio característico do Centro, dispõe de pontos que intensificam os fluxos, como o próprio Parque, a Praça e também, mais especificamente, o terminal de ônibus e o Santuário Sagrado Coração de Jesus. Entende-se, portanto, que a região é um importante polo de lazer e descanso, de acesso ao bairro e de atendimento a um público religioso. Nesse aspecto, foi possível constatar a presença de idosos nos três âmbitos, reafirmando a conveniência do estudo. 

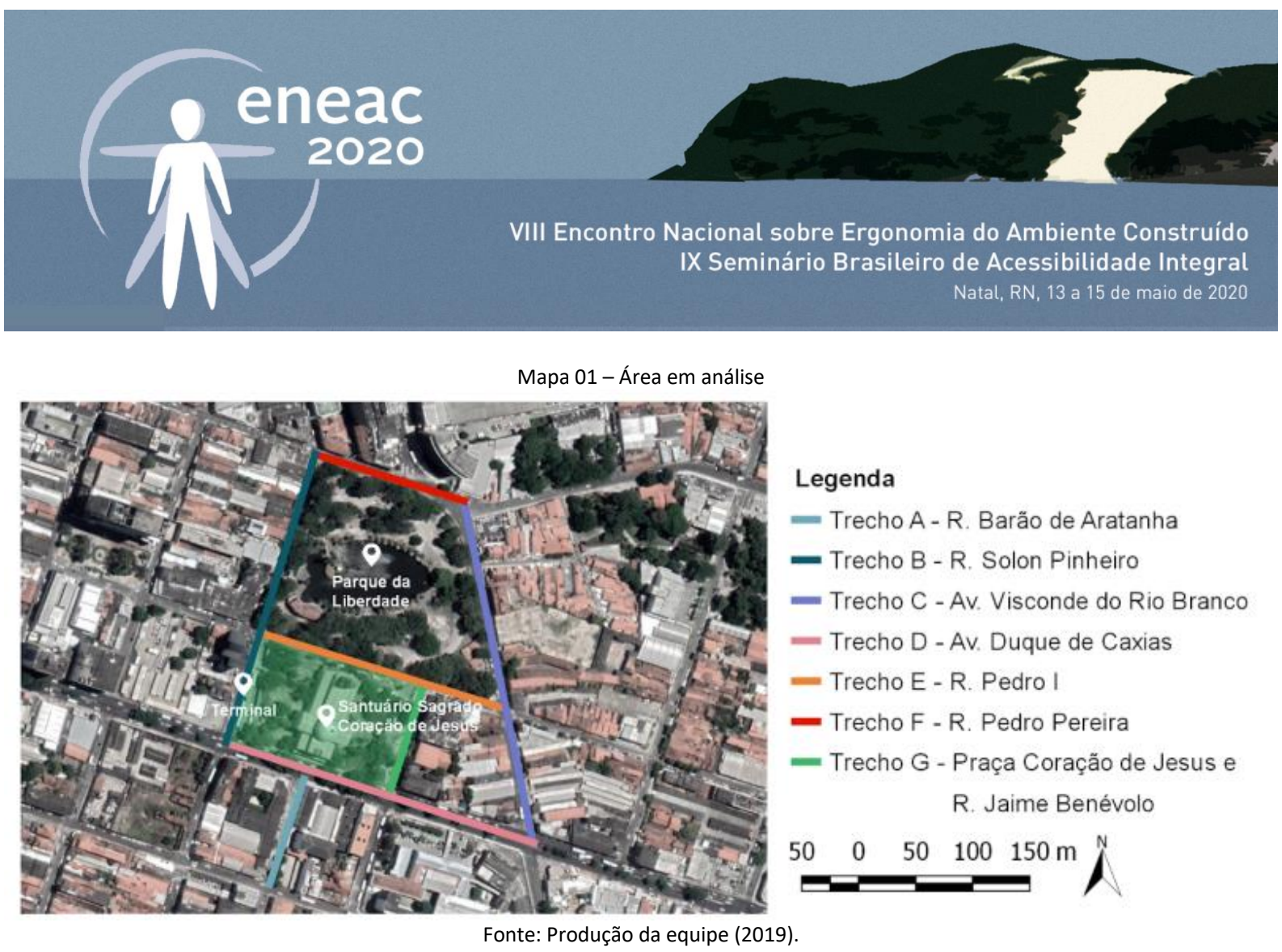

\subsection{Trecho A}

A visita ao Centro iniciou-se pela análise do trecho A que condiz com o quarteirão final da Rua Barão de Aratanha onde encontrou-se principalmente pessoas em trânsito deslocando-se em direção à praça Coração de Jesus no sentido sul-norte. No total, foram contabilizados 6 idosos, sendo 3 homens e 3 mulheres. Na rua era possível encontrar lixo jogado nos dois lados da calçada e não havia lixeiras, bocas de lobo e grelhas.

Quanto à acessibilidade, as calçadas estavam em irregularidade com pavimentação variando em pedra portuguesa, cerâmica e concreto com rachaduras não havendo estabilidade para uma caminhabilidade segura. Além disso, a faixa contínua de circulação dos pedestres era, por vezes, prejudicada, tendo um dos trechos de aproximadamente $1,15 \mathrm{~m}$ com a presença de carros avançando sobre a calçada e uma área com a passagem interrompida, impossibilitando a passagem de um idoso cadeirante sem o auxílio de alguém, por exemplo.

No geral, havia faixa de pedestres sinalizando travessias não semaforizadas e guias rebaixadas tanto na esquina quanto no meio de quadra. Como mobiliário urbano, havia a presença de dois bancos em concreto em um dos lados e a presença de jardineiras, sendo isso bastante útil para garantir o conforto e bem-estar do pedestre, fornecendo momentos de descanso essenciais no trajeto. A iluminação pública também foi assegurada e a presença das poucas árvores estava influenciando a pavimentação das calçadas de maneira negativa. 

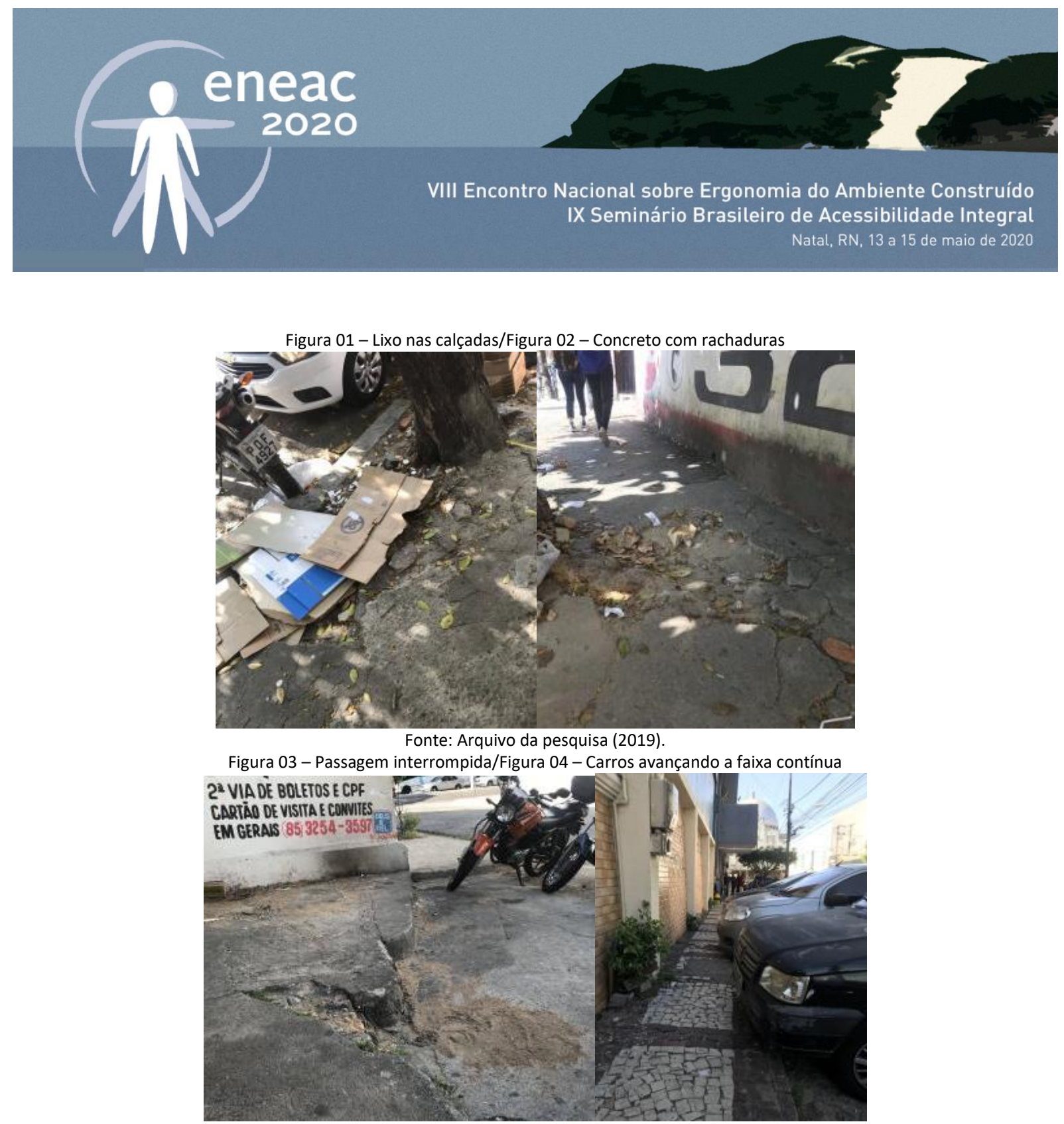

Fonte: Arquivo da pesquisa (2019).

\subsection{Trecho B}

O trecho B confere a Rua Sólon Pinheiro onde foram vistos cerca de 8 idosos, entre eles, 5 mulheres e 3 homens. Possuía, em áreas pontuais, lixo jogado no chão, ausência de lixeiras e presença de bocas de lobo com tampo rachado, além de grelha na rua, atravessando a Pedro I e posicionada em sentido transversal, contrário ao recomendado, e seus vãos resultantes com dimensões maiores que $15 \mathrm{~mm}$, o que poderia gerar acidentes com as rodas de uma cadeira de rodas. 0 passeio apresenta piso regular em frente a algumas lojas, mas rachado ou trepidante em alguns trechos, além da presença de certos obstáculos na faixa livre como a presença de ambulantes, bancas e motos estacionadas ocupando parte da calçada e, ainda, obstáculos aéreos em altura abaixo da recomendada mínima $(2,10 \mathrm{~m})$, como um medidor de energia a 1,30m e ambulantes com guarda sol a cerca de $1,60 \mathrm{~m}$. Ademais, foi possível constatar áreas com inclinações e bastante variação, em que o pior caso se encontra em frente às Casas Freitas com uma inclinação de $17 \%$.

As travessias possuíam rebaixamento de guia da calçada variando em certos pontos com presença de rampa na frente de algumas lojas, na faixa em meio de quadra e rebaixada na travessia de esquina da Rua Pedro I. Existia a travessia semaforizada com faixa de pedestres, porém a faixa existente 


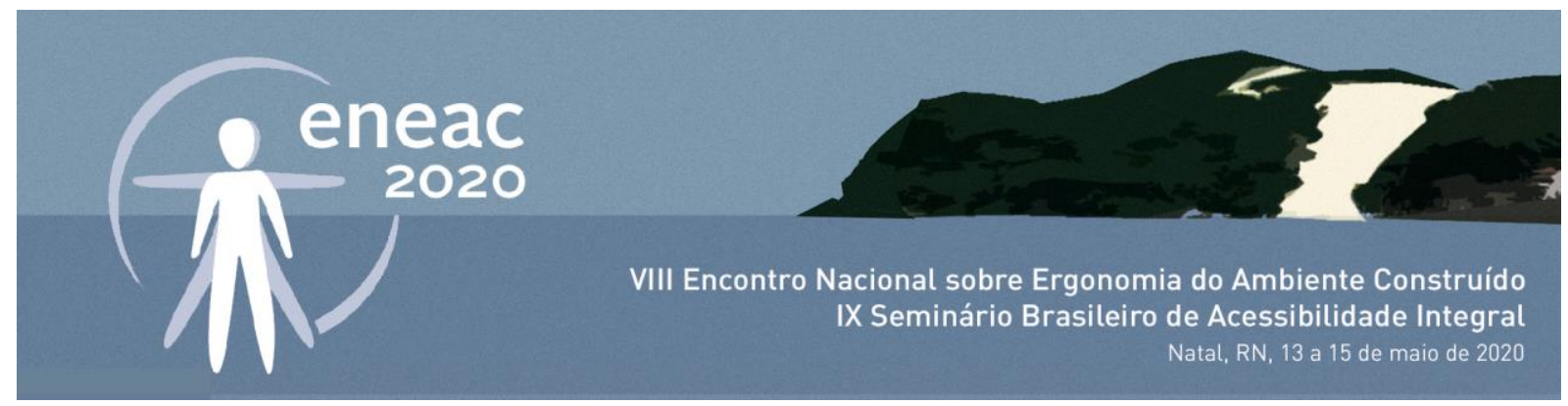

encontrava-se com a sinalização quase apagada, faixa de pedestres e faixa elevada conectando as calçadas.

O mobiliário urbano era inexistente, havendo somente poste de iluminação pública, sem a presença de bancos, jardineiras ou telefone público.

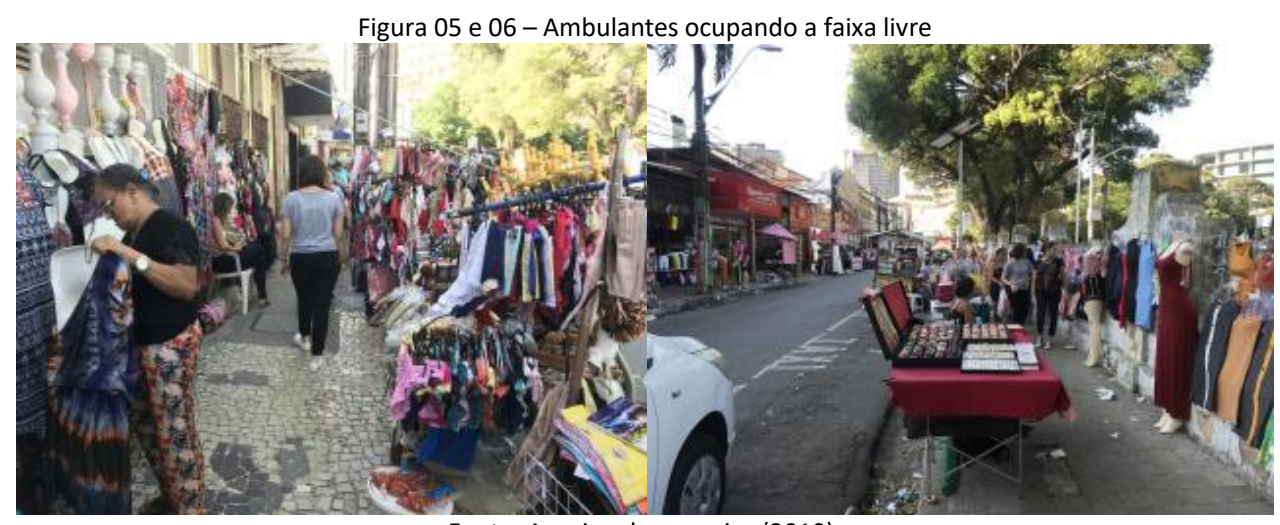

Fonte: Arquivo da pesquisa (2019)

Figura 07 - Grelhas em orientação contrária à recomendada/Figura 08 - Calçada com inclinação de $17 \%$

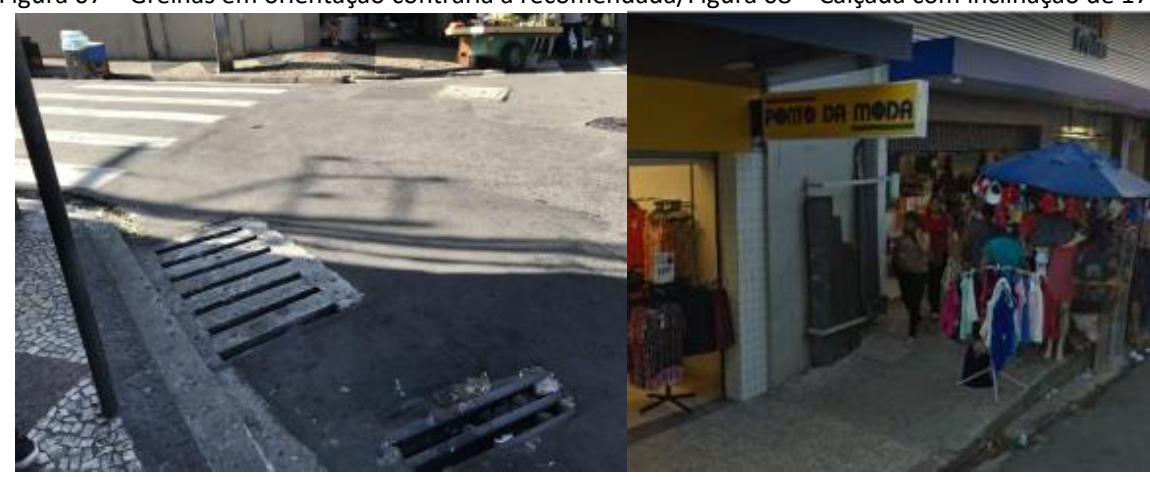

Fonte: Arquivo da pesquisa (2019)/Google street view images

\subsection{Trecho C}

Correspondendo a Avenida Visconde do Rio Branco, o trecho C mostrava-se bastante vazio e com a maioria das fachadas impermeáveis visualmente causando sensação de insegurança. Assim, foram vistos apenas 3 idosos, sendo estes uma mulher e dois homens.

Quanto a limpeza e infraestrutura, foi possível observar muito lixo dos dois lados da calçada, provavelmente, não coletado há dias, sendo encontrada apenas uma lixeira de ferro. Havia presença de caixas de telefone e de energia com concreto rachado ao redor do tampo prejudicando a passagem. A acessibilidade foi ainda mais prejudicada devido à variação de pavimentação em piso intertravado, concreto com rachaduras e a variação de piso com batentes, às vezes. Na faixa contínua de pedestres também havia obstáculos como uma placa bem no meio deixando $0,74 \mathrm{~m}$ livres de um lado e $0,72 \mathrm{~m}$ do outro, presença de área com apenas $1,00 \mathrm{~m}$ de passagem seguido de rampa de $24 \%$ e área com inclinação de $8 \%$ logo no começo da rua, de frente ao Pet Shop. Os obstáculos aéreos presentes eram uma caixa de telefone a 1,40m e um orelhão muito baixo, aproximadamente a $1,50 \mathrm{~m}$. 


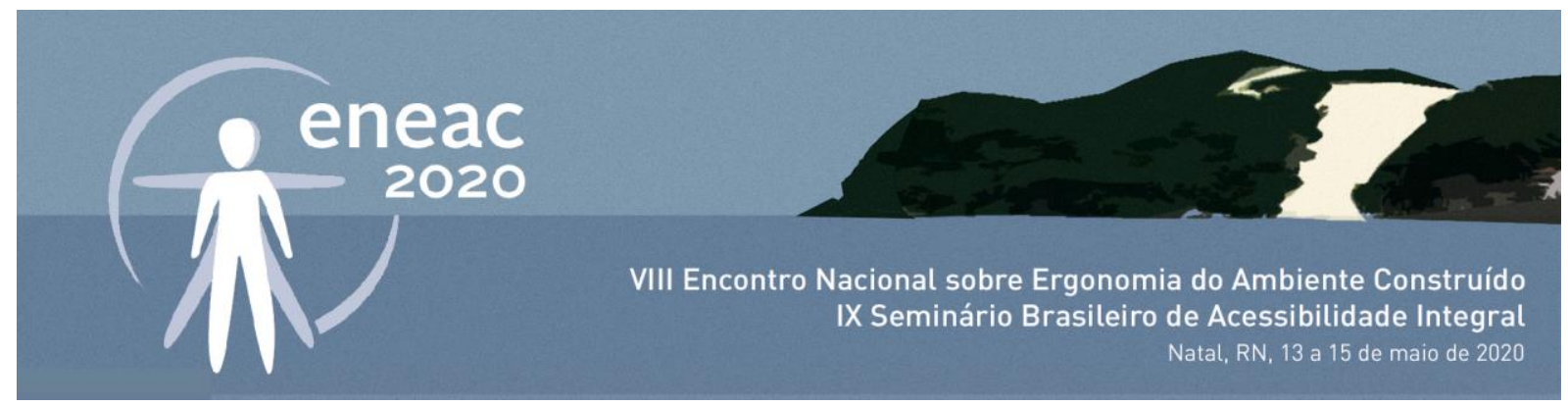

Havia apenas um rebaixamento de guia da calçada no final da rua, no entanto, a rampa tinha inclinação de $19 \%$ e estava sem faixa de pedestres. Conquanto, havia travessia semaforizada com faixa de pedestres.

Como mobiliário urbano, foram encontrados um telefone público e postes de iluminação e o ponto de ônibus existente possuía abrigo na parada. Além disso, o trecho era pouquíssimo arborizado, ocasionando bastante desconforto térmico em determinados horários em que as edificações não geravam sombreamento nas calçadas.

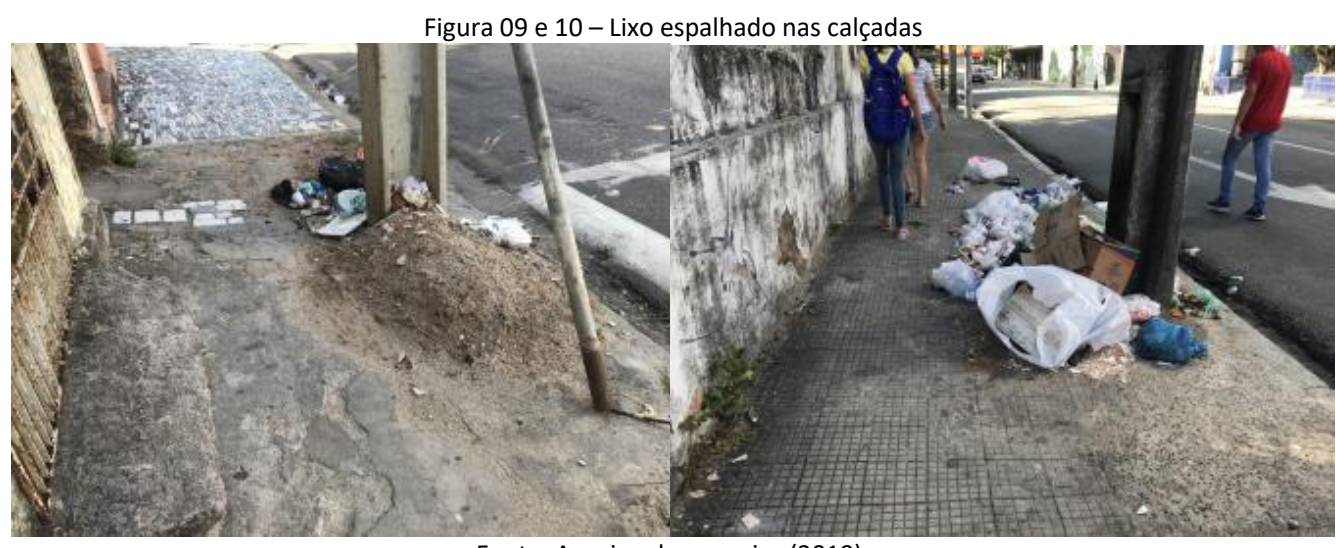

Fonte: Arquivo da pesquisa (2019).

\subsection{Trecho D}

Seguindo para o trecho $\mathbf{D}$ conferindo a Avenida Duque de Caxias, foi possível notar maior concentração de pessoas e de veículos, sendo plausível contabilizar aproximadamente 12 idosos durante a visita.

Foi visto um pouco de lixo em algumas áreas do trecho que também não possuía lixeiras e presença de caixas de esgoto e energia no chão com rachaduras no tampo. As calçadas eram prioritariamente de pedra portuguesa (trepidante) e concreto com rachaduras em alguns pontos mas bem conservado em outros. A faixa livre era descontínua pelo seu interrompimento com rampas de entrada e saída de veículos em frente a Estácio e em outro ponto apenas 1,16m de faixa era livre em frente a Superzon devido a uma rampa de inclinação de $10 \%$. Ademais, os obstáculos aéreos presentes eram os de banca com guarda sol baixo a $1,60 \mathrm{~m}$ de altura.

A travessia por guia rebaixada existente era através de uma rampa de 19\% sem faixa para atravessar a rua Jaime Benévolo e a travessia semaforizada estava com a faixa de pedestres com a sinalização apagada, possuindo ainda semáforo para pedestres.

O transporte público é bastante presente no trecho em questão em que os pontos de ônibus apresentavam sinalização vertical e abrigo na parada. A via é bastante iluminada pelos postes de iluminação, no entanto, tirando os bancos para espera dos ônibus, não havia bancos, telefones públicos ou jardineiras. A presença de árvores estava predominantemente no meio fio, não trazendo prejuízos ao passeio, não gerando sombra suficiente para proporcionar bem-estar ao pedestre. 

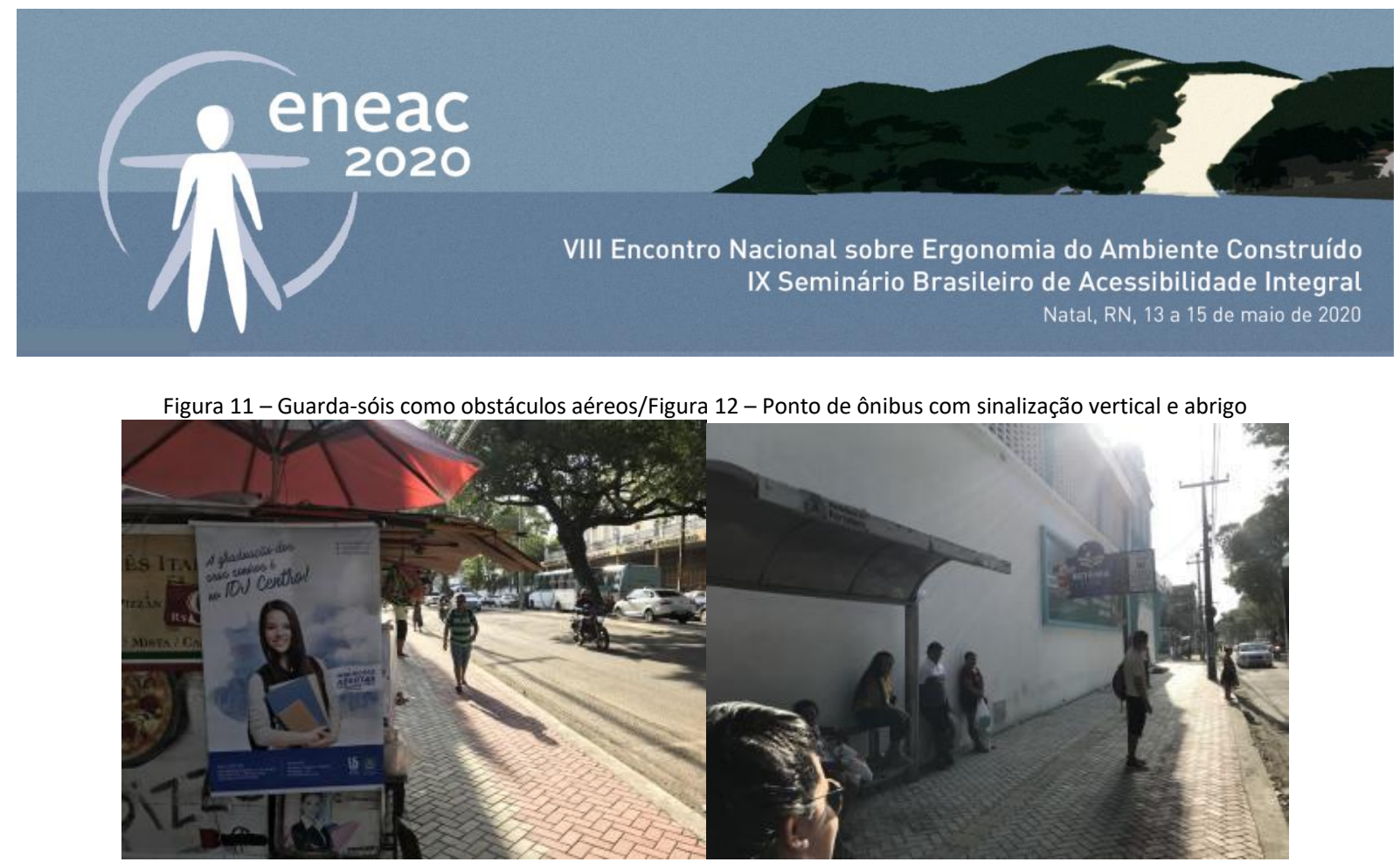

Fonte: Arquivo da pesquisa (2019).

\subsection{Trecho E}

No trecho E, correspondente a Rua Pedro I, percebeu-se pouco movimento durante a análise, sendo ele mais expressivo na área em que havia as paradas de ônibus próximas ao terminal. Foram vistos aproximadamente 5 idosos em circulação, sendo desses 4 homens e apenas 1 mulher. $O$ trecho se encontrava limpo em sua maior parte, mas ainda com lixo jogado em alguns pontos. As lixeiras de concreto só estavam presentes em um dos lados da rua.

A calçada, no geral, possuía o espaço mínimo de $1,20 \mathrm{~m}$ para circulação, havendo apenas dois pontos com espaço reduzido (duas passagens de apenas $1 \mathrm{~m}$, outra de apenas $0,80 \mathrm{~m}$ ) devido a um poste $e$ placas de sinalização. $O$ piso é todo em concreto mas com presença de algumas rachaduras capazes de interferir no caminhar seguro de qualquer pessoa. Também possuía uma pequena área no começo do trecho com inclinação de $8 \%$, desrespeitando a inclinação máxima recomendada pela norma.

Próximo a metade do trecho $E$, a calçada se encaminha para uma faixa elevada ainda sem pintura e, em determinado ponto, também apresenta duas rampas de $17 \%$ de inclinação, ambas em meio de quadra, mas sem faixa de pedestres. Havia um momento em que a calçada era interrompida, dando espaço para a saída de carros da Praça das Crianças, sem inclinações para permitir a descida segura e ainda com mudança drástica de pavimentação regular para trepidante.

No geral, o trecho recebe iluminação pública adequada e todas as paradas de ônibus existentes são sinalizadas e abrigadas. Porém, notou-se que o trecho em questão não apresentava bancos, telefones públicos ou jardineiras. 


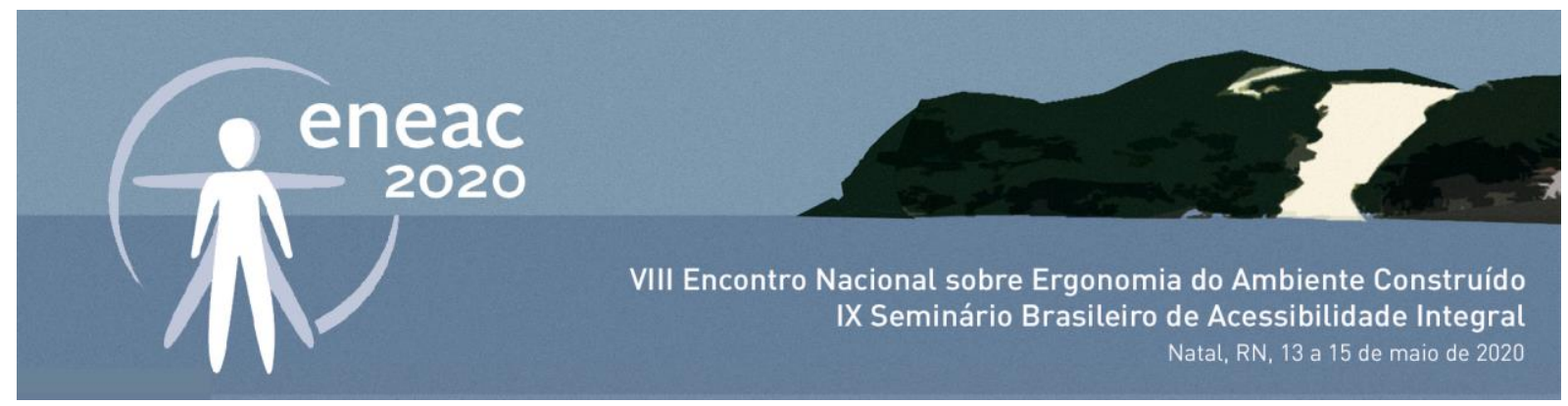

Figura 13 - piso da calçada trepidante e com rachaduras /Figura 14 - calçada interrompida para saída de carros do Parque da Criança.

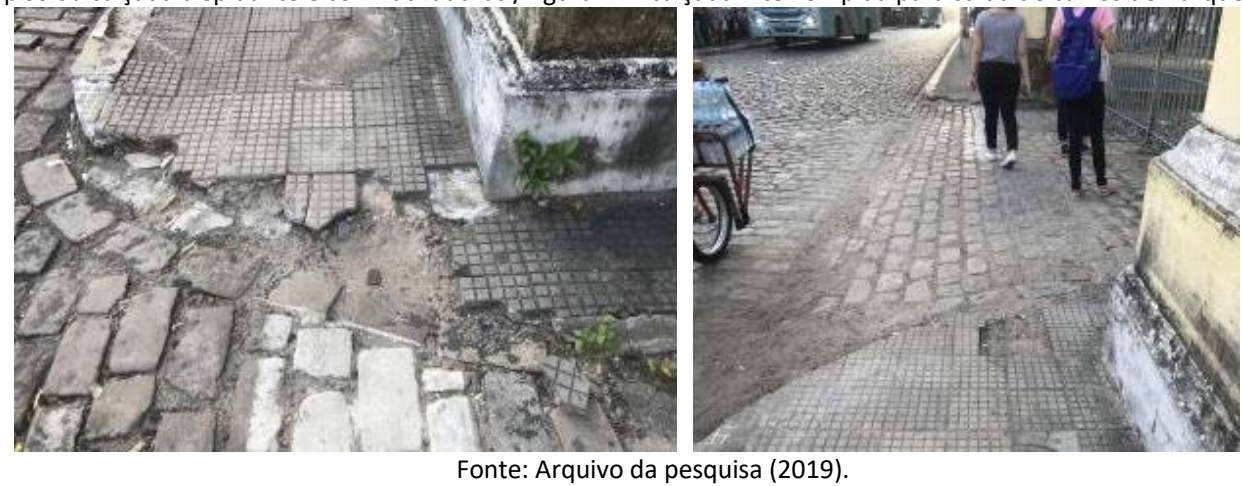

\subsection{Trecho F}

Logo em seguida foi feita a análise do trecho F, a Rua Pedro Pereira, atrás do Parque das Crianças, também com pouco movimento no período da tarde. Foram vistos 5 idosos durante o percurso, sendo 3 homens e 2 mulheres. As calçadas estavam surpreendentemente limpas e ambos os lados eram equipados com lixeiras de concreto.

A pavimentação das calçadas era, em sua maior parte, em blocos de ladrilho hidráulico já com muito desgaste e peças ausentes. As demais áreas eram em piso de concreto e possuíam diversas regiões com rachaduras profundas, dificultando o fluxo de pedestres. Observou-se também que um dos lados possuía dois momentos com menos de $1,20 \mathrm{~m}$ livres para passagem, ambas devido a um poste que deixava apenas $1,08 \mathrm{~m}$ livre e outro deixando apenas $0,80 \mathrm{~m}$. Além disso, havia um poste com uma caixa de energia alocada a 1,95m de altura, tornando possível a colisão de um pedestre desatento.

Uma das calçadas também possuía uma rampa de $24 \%$ de inclinação em meio de quadra, com faixa de pedestre semaforizada, mas sem rampa para chegada do outro lado da rua. Por sua vez, na rua, próximo a esquina com a Rua Solon Pinheiro, havia uma grelha com vãos grandes e perpendiculares à calçada, sendo este um forte obstáculo para pessoas de cadeira de rodas, carrinhos de bebê etc.

O trecho possuía apenas uma parada de ônibus sinalizada, mas sem abrigo ou bancos, tornando desconfortável a espera por transporte público. Não possuía nenhum tipo de mobiliário urbano, apenas as lixeiras e postes de iluminação.

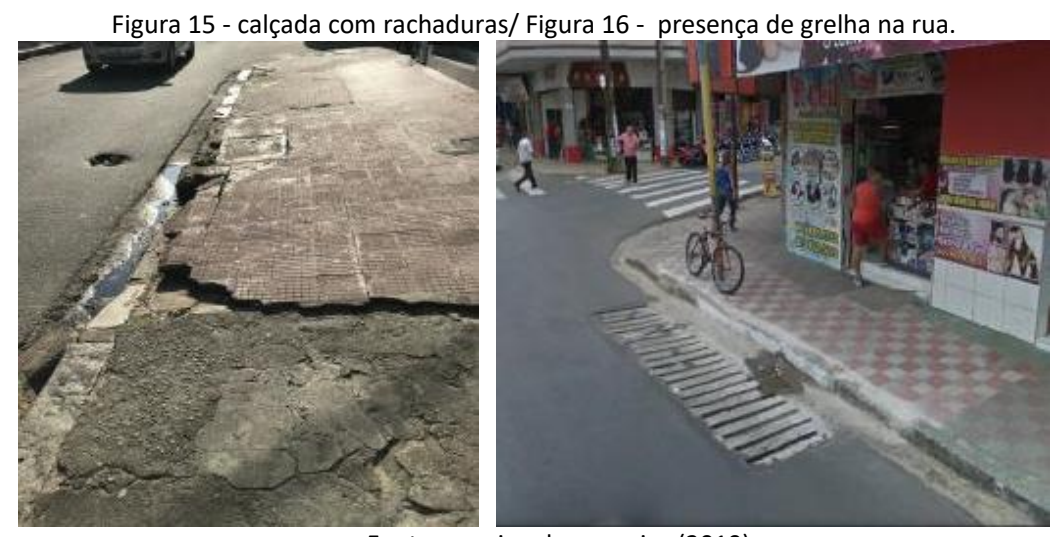

Fonte: arquivo da pesquisa (2019). 


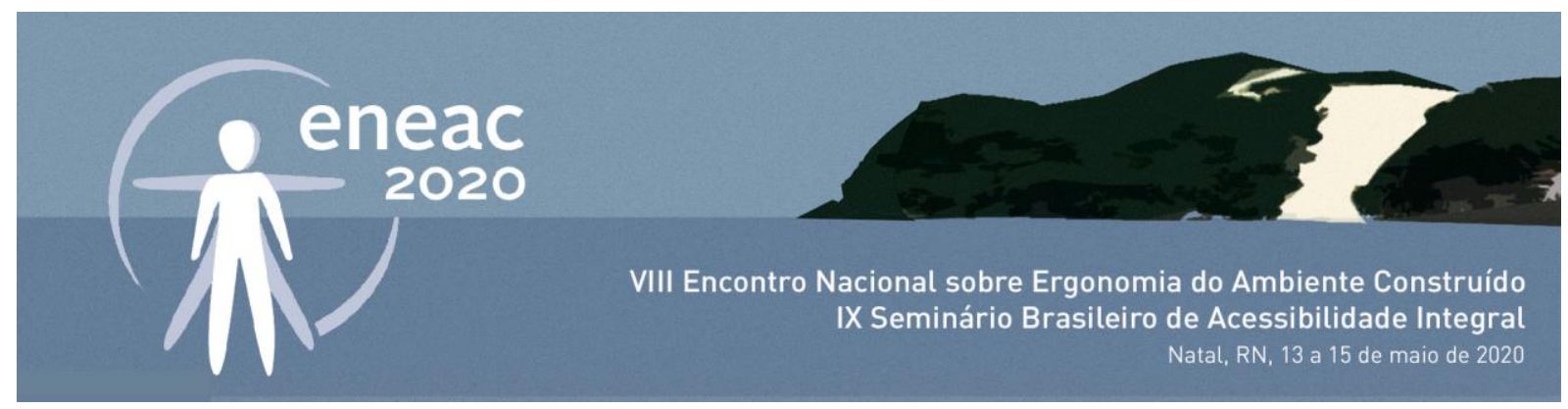

\subsection{Trecho G}

O trecho G foi o último analisado, correspondente a Praça Coração de Jesus juntamente com a Rua Jaime Benévolo que acompanha a praça pelo lado direito. A praça é um espaço bastante movimentado durante o dia, recebendo pessoas de diversas partes da cidade que chegam pelo terminal e frequentam o Centro por motivos de trabalho, saúde, lazer, compras, finanças, estudos ou serviços. Por conta disso, esse foi o trecho onde foi visto o maior número de idosos que se encontravam entrando e saindo dos ônibus, sentados nos bancos da praça, jogando xadrez, fazendo caminhada ou apenas passando pelo trecho como parte de suas rotas.

A praça é toda pavimentada em concreto que se encontra em bom estado em sua maioria, mas com pequenos trechos com rachaduras. A praça também apresenta piso tátil que guia para o terminal e para as faixas de pedestre. O fluxo por ela é bastante livre, havendo bastante espaço de circulação, porém foram observados dois pontos com passagens de menos de 1,20m livres, por conta dos canteiros que deixaram apenas $1,10 \mathrm{~m}$ livre em um ponto e $0,56 \mathrm{~m}$ em outro. Outro fator dificultador da circulação acessível é a presença das bancas de vendedores ambulantes que, em sua maioria, são equipadas com guarda-sóis baixos, a uma altura de cerca de 1,60m, com o madeiramento muitas vezes passando da lona, tornando a possível colisão ainda mais perigosa.

A praça possui postes de iluminação e é equipada com várias lixeiras de concreto espalhadas, mas mesmo assim é possível perceber uma quantidade considerável de lixo espalhado pelo chão. Outro fator importante observado é a presença de uma grelha posicionada perpendicularmente à plataforma do terminal, tornando dificultado o trajeto praça-terminal e vice-versa.

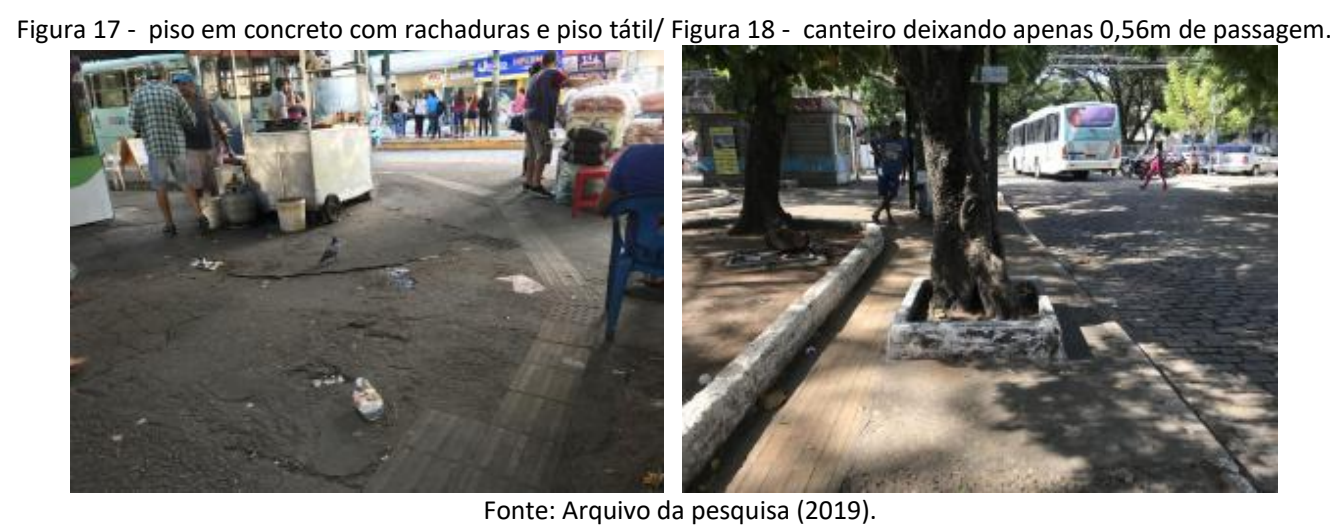

A Igreja do Sagrado Coração de Jesus, localizada no centro da praça, é um dos destinos principais de muitas das pessoas que frequentam o Centro de Fortaleza, portanto, ela deveria ser acessível a todos os seus visitantes. A entrada principal da igreja encontra-se elevada do nível da praça, sendo necessário o acesso pela escada frontal, pelas duas rampas laterais ou pela escada lateral. A rampa do lado esquerdo da Igreja possui inclinação de $7 \%$ e a rampa do lado direito possui inclinação de 10\%. A escada frontal não possui corrimão, mas ele está presente na escada lateral, porém sem as barras intermediárias. A igreja também possui uma entrada pela parte de trás. que pode ser acessada por uma rampa existente tanto no lado direito quanto no lado esquerdo, ambas com inclinação de 21\%. É possível perceber, portanto, que nenhum dos acessos à Igreja do Sagrado Coração de Jesus é completamente acessível a todos os públicos. As rampas possuem inclinação superior ao recomendado pela norma que seria de no máximo 6,33\% para permitir a adequada subida e descida da cadeira de rodas. Os corrimãos são de extrema importância, mas, além das 


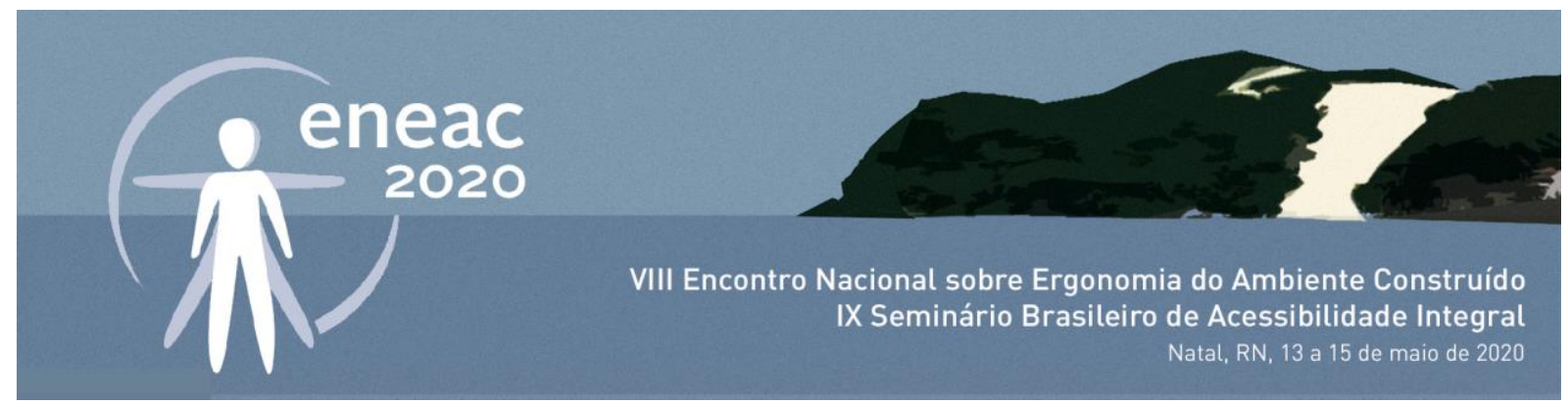

barras externas, devem possuir as barras intermediárias para garantir a máxima segurança de quem nele se apoia.

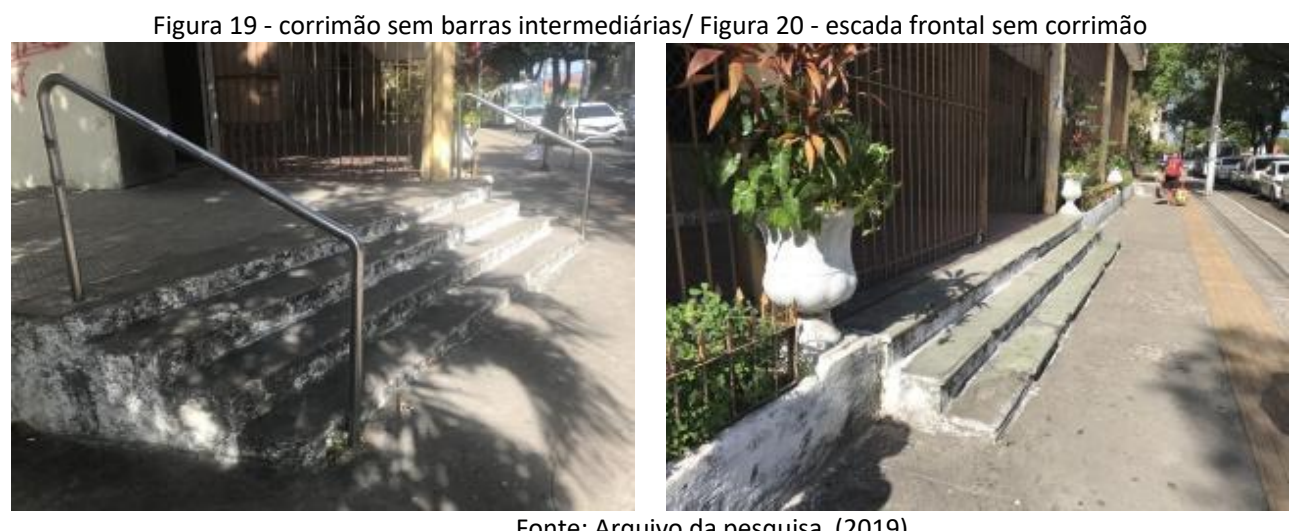

Fonte: Arquivo da pesquisa (2019).

A praça também conta com o Terminal Coração de Jesus, que recebe 26 linhas de ônibus, tornando esta uma região bastante movimentada. As paradas que se encontram sobre a plataforma são todas abrigadas e sinalizadas, porém sem nenhum tipo de guarda corpo. 0 ônibus estaciona e deixa suas portas quase que totalmente niveladas com a plataforma. As paradas localizadas fora das plataformas nem sempre são abrigadas, mas são todas sinalizadas.

Por fim, ainda pertencente ao trecho G, foi feita a análise da Rua Jaime Benévolo. Sua calçada era toda em concreto com algumas rachaduras pontuais. A calçada possuía dimensões bastante generosas e apresentava várias áreas com $1,20 \mathrm{~m}$ livres de passagem. Porém, algo que chamou bastante atenção durante o percurso foi a presença de vários carros estacionados em cima da calçada ou avançando sobre ela, diminuindo consideravelmente o espaço disponível de passagem. Além disso, foram contabilizadas três rampas, todas elas sem faixa de pedestres e com inclinações inadequadas $(21,26 \%, 8,75 \%$ e $23 \%)$. Sobre uma delas havia um carro estacionado.

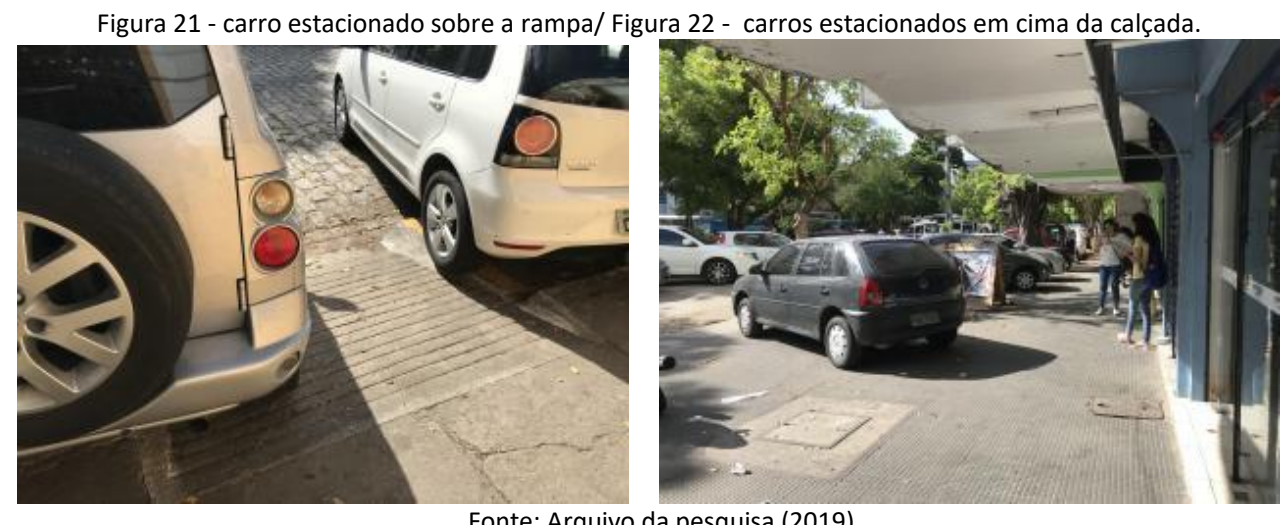

\subsection{Lotes acessíveis e não acessíveis}

Para finalizar a pesquisa, foi feita também uma breve análise de cada lote presente nos trechos, considerando a questão da acessibilidade e da permeabilidade das fachadas, tanto de dia quanto de noite. Observou-se que grande parte dos lotes (em sua maioria lojas, lanchonetes ou algum tipo de 


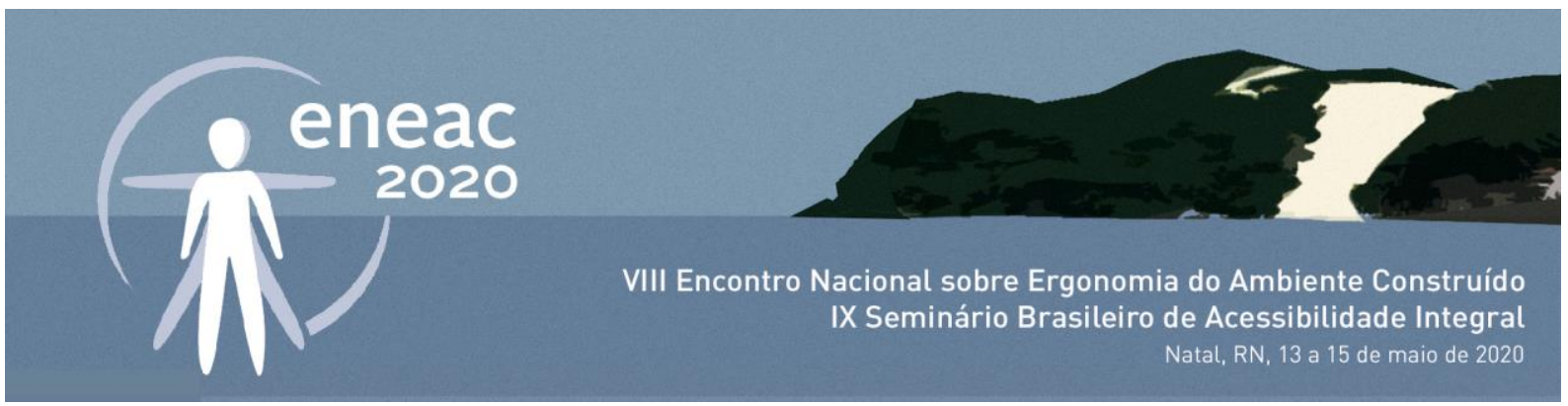

empreendimento), não se encontram nivelados com as calçadas e foram feitas intervenções nem sempre acessíveis para garantir o acesso. Altos degraus e escadas são comuns, sendo pouco frequente o uso de rampas ou até mesmo do nivelamento da entrada. O mapa a seguir traz essa síntese.

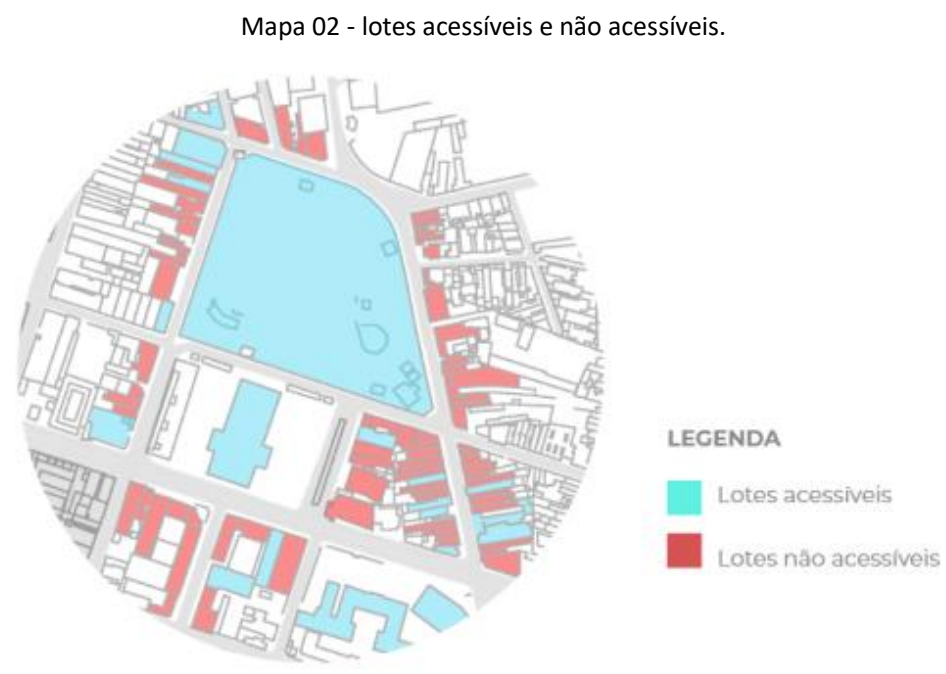

Fonte: Produção da equipe (2019).

\subsection{Fachadas permeáveis e não permeáveis}

Com relação à permeabilidade das fachadas, percebeu-se que a maioria é bastante visível durante o dia, com vitrines ou fachadas coloridas e chamativas, buscando atrair principalmente a atenção dos pedestres. Algumas não se mostram permeáveis, provavelmente lotes abandonados, em reforma, ou em transição de uso. O mapa a seguir apresenta quais lotes se mostram sempre permeáveis, sempre não permeáveis ou cuja permeabilidade varia durante o dia. É possível perceber que o trecho da Rua Sólon Pinheiro e da Av. Duque de Caxias possuem uma grande quantidade de lotes cuja permeabilidade varia durante o dia. Trata-se de lojas, lanchonetes ou estabelecimentos prestadores de serviços e tal fato confere a essas duas ruas bastante movimento durante o dia, tanto de veículos quanto de pedestres. Já o trecho da Av. Visconde do Rio Branco possui a maior parte dos seus lotes como sempre não permeáveis. Este é um trecho de caráter de certo abandono, com lotes fechados e sem funcionamento ou de baixo movimento. Por conta disso, esse se tornou um trecho de pouco movimento de pedestres e de veículos. Como lotes sempre permeáveis há o destaque para o Parque das Crianças, um ambiente aberto que pode ser acessado a qualquer horário e a Universidade Estácio, que, embora seja um ambiente privado, possui muros baixos e grades que permitem a visibilidade de seu interior.

Observou-se também que, com a chegada da noite e o encerramento do expediente, todos os empreendimentos fecham suas portas, tornando as ruas extremamente quietas e sem movimento, sendo este um dos principais fatores que tornam o Centro de Fortaleza pouco frequentado durante a noite. 


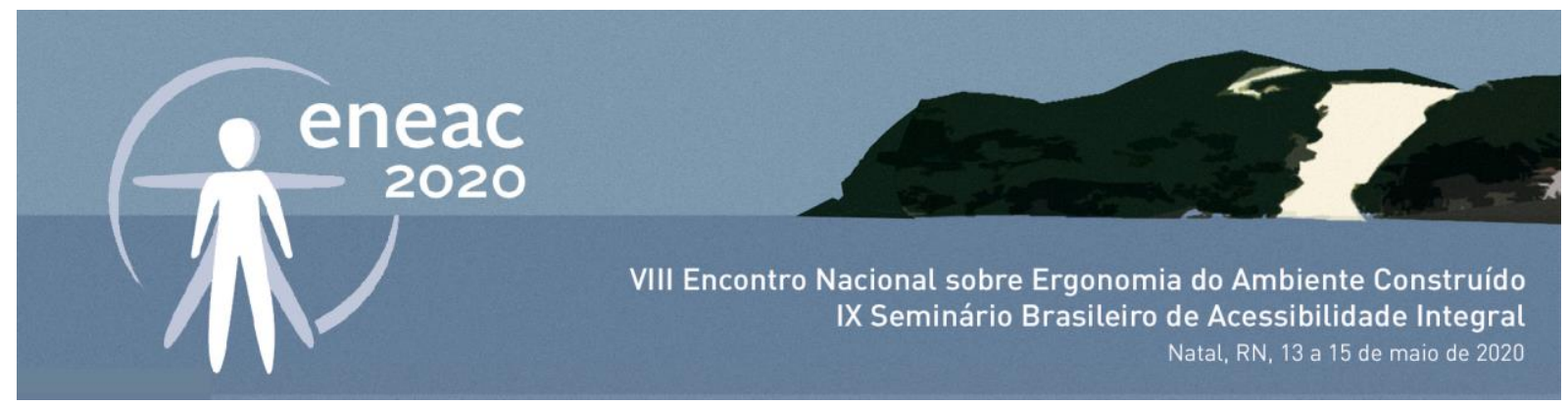

Mapa 03 - permeabilidade dos lotes

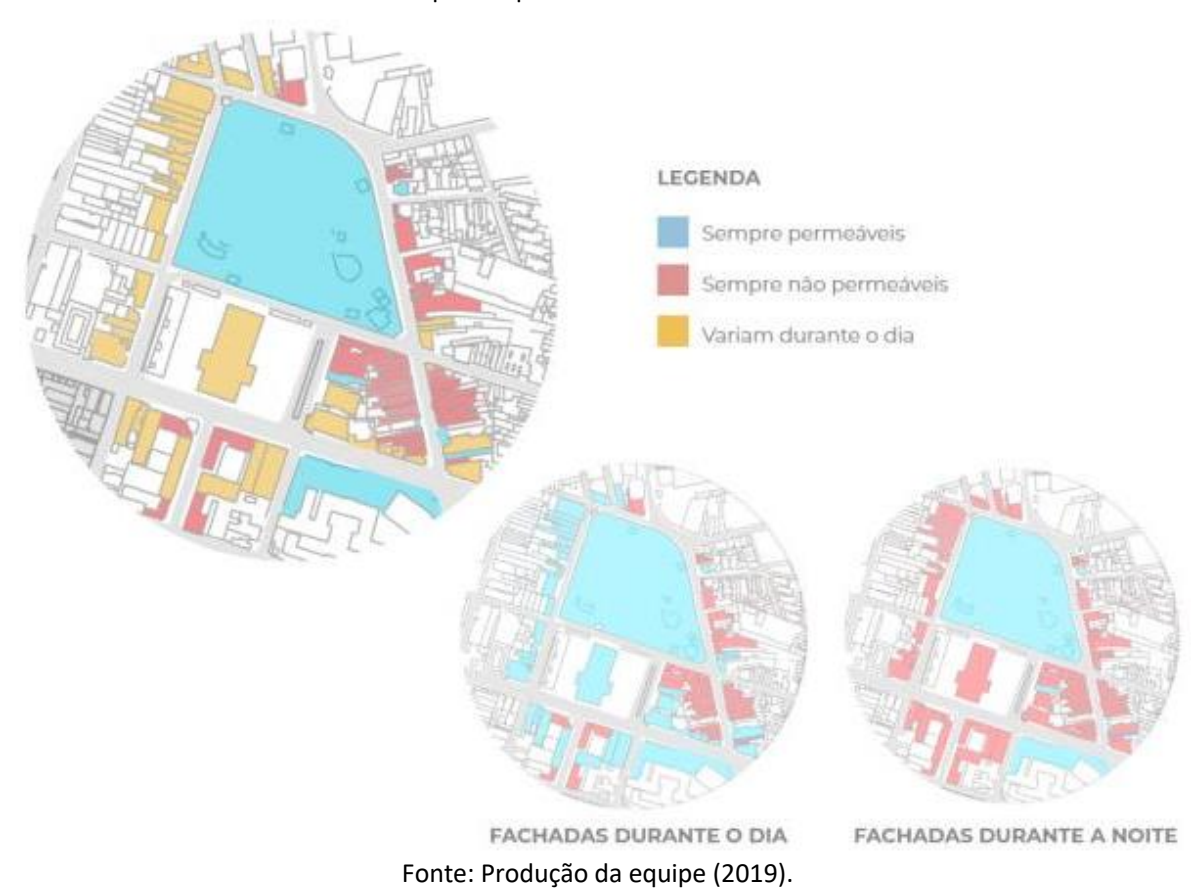

\subsection{Entrevistas}

Durante os dois dias de visita ao Centro, foram entrevistados 7 idosos, destes 5 homens e 2 mulheres. Todos encontravam-se caminhando sozinhos e em seu próprio ritmo pelos trechos ou pela Praça Coração de Jesus. Segundo os dados coletados, 6 deles haviam chegado ao centro de ônibus e apenas um havia vindo a pé, pois morava nas imediações. Dois idosos vieram de bairros relativamente próximos como Dionísio Torres e Bela Vista que distam, respectivamente, cerca de 5 e $7 \mathrm{~km}$ do Centro. Os demais eram moradores de bairros mais distantes como Jangurussu, Bela Vista, Messejana e Lagoa Redonda que se encontram a cerca de $15 \mathrm{~km}$ do Centro. As motivações das visitas eram variadas, voltadas para trabalho, compras e lazer.

\section{CONSIDERAÇÕES FINAIS}

Ao final do trabalho pode-se concluir que o trecho estudado não apresenta adequadas condições de acessibilidade aos seus usuários. Muitos idosos ainda recorrem ao Centro como espaço de lazer, trabalho e compras, partindo de diversos bairros da cidade. Portanto necessitam de um ambiente regular para caminhar, estar e descansar, assim como mobiliários para descanso devido a necessidade de pausas em suas caminhadas pelo corpo fragilizado.

Os principais problemas de acessibilidade diagnosticados caracterizam barreiras físicas, como o comércio ambulante ocupando grande parte das calçadas, os veículos estacionados sobre rampas e calçadas, a pavimentação trepidante, inexistente ou quebrada e o acúmulo de lixo. Sobre o transporte coletivo, constatamos que grande maioria dos transeuntes utilizam o transporte público 


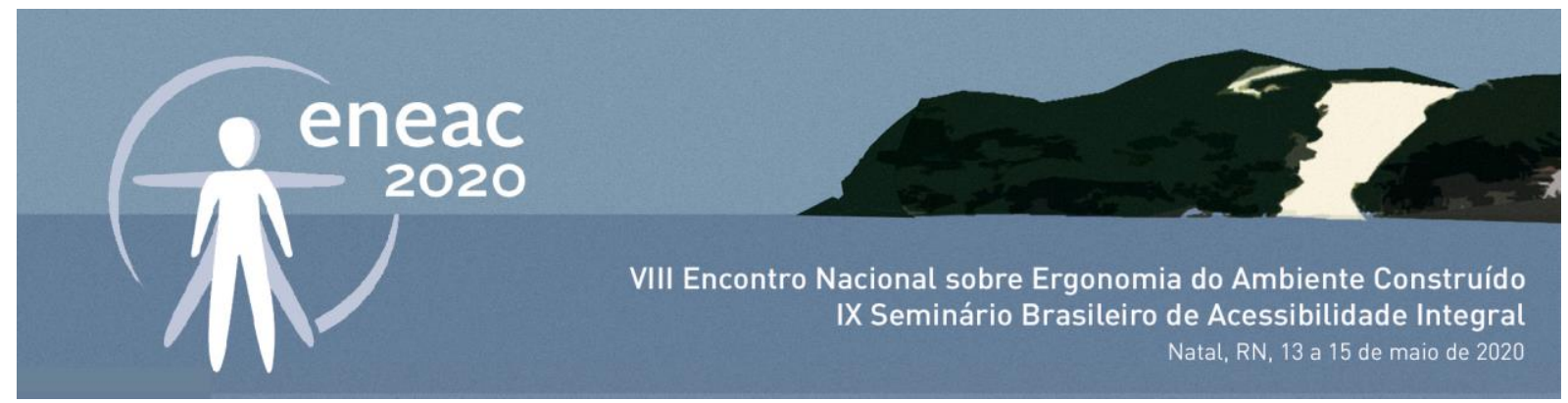

ou deslocam-se a pé. O trecho estudado é um polo de grande fluxo de coletivos, no entanto, não atende às condições necessárias de acesso e segurança. Outro problema que também deve ser evidenciado é a segurança do Centro e como isso afeta mais o público feminino. Em nossa pesquisa, no geral, encontramos mais idosos do sexo feminino do que o masculino, no entanto, nas ruas menos movimentadas encontramos mais idosos do sexo masculino.

Com a realização da pesquisa e apresentação dos resultados temos como objetivo evidenciar a importância da acessibilidade nos espaços públicos, disseminar a cultura da inclusão, abordando o tema principalmente para o público idoso, que continua sendo frequentadores assíduos e que deve ter voz ativa na formulação de intervenções junto ao poder público.

\section{AGRADECIMENTOS}

Agradecemos a professora Zilsa Santiago por ministrar com grande excelência a disciplina de Desenho Universal e por nos fazer ter novas visões para situações rotineiras que às vezes nos passam despercebidas. Agradecemos também a mestranda Manuela Lima pela oportunidade de participar de sua pesquisa durante o desenvolver da disciplina. Decerto esta foi uma experiência que nos trouxe bastante aprendizado e sensibilidade para nosso desenvolvimento profissional como futuras arquitetas e urbanistas. Por fim, agradecemos umas às outras, por todo o esforço, empenho e parceria na produção do estudo apresentado neste artigo.

\section{REFERÊNCIAS}

ABNT NBR 9050. Acessibilidade a edificações, mobiliário, espaços e equipamentos urbanos. Rio de Janeiro: ABNT, 2015.

BOTELHO, Tarcísio R. Revitalização de centros urbanos no Brasil: uma análise comparativa das experiências de Vitória, Fortaleza e São Luís. Revista eure (Vol. XXXI, № 93), pp. 53-71, Santiago de Chile, 2005.

LIMA, Eryane Vieira; SANTANA, Kalyana Lordelo De; NUNES, Laís Síntique Pedroza Oliveira; CAMPOS, Neiva Carla Lessa; SANTOS, Tainá Gomes Dos; SILVA, Larissa Scarano Pereira Matos Da; "Acessibilidade no Centro histórico de Laranjeiras - SE: Do direito à ação", p. 235-247 . In: . São Paulo: Blucher, 2018.

ROCHA, Carlos Bruno Oliveira; SANTIAGO, Zilsa Maria Pinto; RIBEIRO, Fernanda Lessa; "Espaço público e espaço edificado: Uma análise dos equipamentos sociais agregados às praças do Centro de Fortaleza sob o enfoque da acessibilidade universal", p. 222-234 . In: . São Paulo: Blucher, 2018.

SANTIAGO, Zilsa Maria Pinto; SANTIAGO, Cibele Queiroz de; SOARES, Thais Silveira. Relatório Técnico de Pesquisa: Análise das condições de acessibilidade espacial de praças e equipamentos sociais sob o enfoque do desenho universal. Estudos de caso: Centro e bairros Aldeota; Fátima e Benfica em Fortaleza. PIBIC 2014/2015 - Edital 01/14. Pró-Reitoria de Pesquisa e Pós-Graduação. Universidade Federal do Ceará, 2015 